\title{
ANALISIS PELAKSANAAN MGMP IPS SMP/MTS DALAM MENINGKATKAN PROFESIONALITAS GURU DI KABUPATEN SIJUNJUNG TAHUN 2017
}

\author{
Suci Wulandari \\ Mahasiswa S1 Program Studi Pendidikan Geografi, FIS UNP \\ Dosen Jurusan Geografi, FIS UNP \\ E-Mail : $\underline{\text { Suciwulandaripiliang@Gmail.Com }}$
}

\begin{abstract}
ABSTRAK
Penelitian ini bertujuan untuk mengetahui kendala, upaya, manfaat MGMP dalam meningkatkan profesionalitas guru. Jenis penelitian ini adalah deskriptif kualitatif, informan dalam penelitian ini adalah peserta MGMP IPS Gugus 2 Kabupaten Sijunjung. Informan yang berjumlah 6 orang. Cara menentukan informan dengan teknik Purposive sampling. Teknik pengumpulan data yang digunakan dalam penelitian ini adalah observasi, wawancara dan dokumentasi. Teknik analisis data yang digunakan dalam penelitian ini adalah reduksi data, penyajian data dan verifikasi data.

Penelitian ini menghasilkan: 1) kendala dalam pelaksanaan MGMP IPS Gugus 2 Kabupaten Sijunjung diantaranya, masalah pendanaan yang kurang mencukupi, kurangnya partisipasi/keaktifan dari anggota, beberapa peserta kadangkala tidak mengerjakan tugas MGMP, sebagian besar guru belum mengerti tentang penulisan PTK dan perangkat pembelajaran lainnya 2) upaya MGMP dalam meningkatkan profesionalitas guru diantaranya, adanya bantuan dana dari APBD, menyusun program kegiatan sesuai dengan kebutuhan guru seperti penulisan PTK dan perangkat pembelajaran, 3) manfaat MGMP dalam meningkatkan kualitas pembelajaran dan profesionalitas guru diantaranya, guru dapat mendiskusikan permasalahan yang dihadapi di sekolah, memperoleh informasi edukatif pengetahuan, teknologi, dapat bertukar informasi dan pengalaman, memotivasi guru untuk terus meningkatkan kemampuan dan keterampilan dalam merencanakan, melaksanakan, mengevaluasi pembelajaran.
\end{abstract}

Kata kunci : MGMP, Profesionalitas guru

\section{ABSTRACT}

This study aims to determine the constraints, efforts, benefits of MGMP in improving the professionalism of teachers. The type of this research is descriptive qualitative, the informant in this research is MGMP IPS cluster 2 Sijunjung. Informants totaling 6 people. How to determine the informant with Purposive sampling technique. Data collection techniques used in this study are observation, interview and documentation. Data analysis techniques used in this study is data reduction, data presentation and data verification. This study resulted in: 1) obstacles in the implementation of the MGMP IPS Cluster 2 Sijunjung District among others, insufficient funding issues, lack of participation or the activities of the members, some of the participants sometimes did not do the MGMP tasks, most teachers did not understand about the writing of PTK and other learning tools 2) MGMP efforts in improving the professionalism of teachers such as, the support of funds from the APBD, develop program activities in accordance with the needs of teachers such as writing PTK and learning tools, 3) the benefits of MGMP in improving the quality of learning and professionalism of teachers such as, teachers can discuss problems faced in schools, obtain educational information knowledge, technology, can exchange information and experience, motivate teachers to continue to improve skills and skills in planning, implement, evaluate learning

Keywords: MGMP, Professionalism teacher

${ }^{1}$ Mahasiswa Program Studi Pendidikan Geografi untuk Wisuda Maret 2018 


\section{PENDAHULUAN}

Guru merupakan faktor dominan dalam pembelajaran di sekolah, disamping faktor lainnya seperti materi, siswa, metode media dan unsur lingkungan belajar. Guru merupakan kunci utama yang berperan dalam mengembangkan kualitas individu menjadi warga negara yang memahami ilmu dan teknologi. Bagaimanapun sarana dan prasarana, alat bantu kurikulum dan faktor lain tak akan ada artinya apabila guru tidak mampu mengkoordinir semua sumber belajar menjadi hal yang berguna. Jadi guru adalah faktor penentu kualitas pendidikan, dimana peran guru sebagai tenaga pengajar sekaligus sebagai pendidik sangat besar dalam melahirkan generasi-generasi yang berkualitas melalui pendidikan, sebaliknya bila kualitas guru rendah, maka kualitas pendidikan juga rendah.

Dalam UU Nomor 14 Tahun 2005 tentang guru dan dosen, pasal 2, dinyatakan bahwa "Guru mempunyai kedudukan sebagai tenaga profesional pada jenjang pendidikan dasar, pendidikan menengah dan pendidikan anak usia dini jalur pendidikan formal yang diangkat sesuai dengan peraturan perundang undangan". Peran dan fungsi guru sangat penting dalam proses belajar mengajar. Oleh karena itu, situasi yang dihadapi guru dalam melaksanakan pengajaran mempunyai pengaruh besar terhadap proses belajar mengajar itu sendiri. Dengan demikian guru sepatutnya peka terhadap berbagai situasi yang dihadapi, sehingga dapat menyesuaikan pola tingkah lakunya dalam mengajar dengan situasi yang dihadapi. Di Indonesia suatu wadah organisasi profesi diatur dalam Undangundang Nomor 14 Tahun 2005 tentang Guru dan Dosen, dikemukakan bahwa "Organisasi Profesi Guru adalah perkumpulan yang berbadan hukum yang didirikan dan diurus oleh guru untuk mengembangkan profesionalitas guru". Lebih lanjut dijelaskan hal-hal sebagai berikut :

1. Pasal 41

(1) Guru dapat membentuk organisasi profesi yang bersifat independen.

(2) Organisasi profesi sebagaimana dimaksud pada ayat berfungsi untuk memajukan profesi, meningkatkan kompetensi, karier, wawasan pendidikan, perlindungan profesi, kesejahteraan, dan pengabdian kepada masyarakat.

(3) Guru wajib menjadi anggota organisasi profesi

(4) Pembentukan organisasi profesi sebagaimana dimaksud pada ayat (1) dilakukan sesuai peraturan perundang-undangan

(5) Pemerintah dan atau pemerintah daerah dapat memfasilitasi organisasi profesi guru dalam pelaksanaan pembinaan dan pengembangan profesi guru. 
2. Pasal 42

Organisasi profesi guru mempunyai kewenangan (Mulyasa, 2008:48) :

(1) Menetapkan dan menegakkan kode etik guru

(2) Memberikan bantuan hukum kepada guru

(3) Memberikan perlindungan profesi guru

(4) Melakukan pembinaan dan pengembagan profesi guru

(5) Memajukan pendidikan nasional

Pasal yang disebut Mulyasa di atas merupakan pasal kebijakan baru yang dikeluarkan oleh pemerintah dalam peningkatan profesionalan guru, sebelumnya sudah ada pasal-pasal yang memuat tentang organisasi guru yaitu pada buku "Potret Guru" ditulis bahwa PGRI dimantapkan sebagai organisasi profesi diperjelas dalam Kongres PGRI XIV yang berlangsung di Jakarta tanggal 26 sampai 30 Juni 1979.

MGMP merupakan suatu wadah professional guru mata pelajaran yang berada pada suatu wilayah Kabupaten/Kota/ Kecamatan. Ruang lingkupnya meliputi guru mata pelajaran pada SMP negeri maupun swasta, baik guru yang berstatus PNS maupun non PNS. Prinsip kerjanya adalah cerminan kegiatan "dari oleh dan untuk guru" dari semua sekolah. Atas dasar ini, maka MGMP merupakan organisasi nonstruktural yang bersifat mandiri, berasaskan kekeluargaan dan tidak mempunyai hubungan hierarki dengan lembaga lain.
MGMP merupakan salah satu jenis organisasi guru-guru sekolah yang diakui pemerintah sampai saat ini selain PGRI. MGMP didirikan atas anjuran pejabat-pejabat Departemen Pendidikan dan Kebudayaan. (Soetjipto, 2009:36 )

MGMP adalah forum atau wadah kegiatan professional guru mata pelajaran sejenis. Hakikat MGMP berfungsi sebagai wadah atau sarana komunikasi, konsultasi, dan tukar pengalaman. MGMP ini diharapkan dapat meningkatkan profesionalisme guru dalam melakanakan pembelajaran yang bermutu sesuai dengan kebutuhan peserta didik. Wadah komunikasi profesi ini sangat diperlukan dalam memberikan kontribusi pada peningkatan kemampuan, wawasan, pengetahuan serta pemahaman guru terhadap materi yang diajarkan dan pengembangannya ( Saondi, 2010:80 )

MGMP adalah suatu forum atau wadah kegiatan professional guru mata pelajaran sejenis disanggar maupun di masing-masing sekolah yang terdiri dari dua unsur yaitu musyawarah dan guru mata pelajaran. MGMP diharapkan akan meningkatkan profesionalisme guru dalam melaksanakan pembelajaran yang bermutu sesuai kebutuhan peserta didik. Wadah profesi ini sangat diperlukan dalam memberikan kontribusi pada peningkatan keprofesionalan para anggotanya (Sa'ud, 2009:107). 
Dari pengertian MGMP di atas, tergambar bahwa MGMP tersebut sebagai wadah kegiatan guru di luar proses belajar mengajar di kelas yang pelaksanaannya diorganisir, dimana guru-guru bermusyawarah, mengkaji permasalahan tugas-tugas guru yang sasarannya peningkatan mutu pendidikan. Organisasi MGMP ini bertujuan untuk meningkatkan mutu dan profesionalisasi dari guru dalam kelompoknya masing-masing. Kegiatan dalam kelompok ini diatur dengan jadwal yang cukup baik. Sayangnya belum ada keterkaitan dan hubungan formal antara kelompok guru-guru dalam MGMP ini dengan PGRI (Soetjipto, 2009:36) Sebagai pengajar seorang guru dituntut kemampuannya untuk mengorganisasikan proses pembelajaran, melaksanakan kegiatan pembelajaran seperti membuat persiapan pengajaran, serta menilai hasil belajar siswa. Hal ini mengisyaratkan bahwa kemampuan mengorganisasi proses pembelajaran juga merupakan suatu hal yang sangat penting bagi seorang guru, karena melalui proses belajar dalam kelas, anak didik akan dapat menilai kemampuan yang dimiliki gurunya yang penting pada dasarnya juga akan berpengaruh pada sikap belajar anak didik. Salah satu cara yang dapat meningkatkan dan mengembangkan kualitas atau profesionalisme guru tenaga kependidikan ialah melalui interaksi teman sejawat antar guru. Untuk itu diperlukan suatu wadah bagi guru yang sama bidang studi yaitu
Musyawarah Guru Mata Pelajaran (MGMP). Menurut Azwir (2006:2) peran Musyawarah Guru Mata Pelajaran (MGMP) adalah: (1) melaksanakan pengembangan wawasan, pengetahuan dan kompetensi sehingga memiliki dedikasi tinggi, (2) melakukan refleksi diri ke arah pembentukan guru profesional sehingga MGMP yang berkedudukan di Kabupaten Sijunjung diharapkan dapat berkolaborasi dengan Dinas Pendidikan Kabupaten Sijunjung dan Kepala Cabang Dinas Kecamatan.

Sebagai wadah musyawarah MGMP IPS Kabupaten Sijunjung diharapkan dapat meningkatkan kualitas pembelajaran bagi guru dalam merencanakan, melaksanakan, mengevaluasi pengajaran di sekolah. Kegiatan MGMP yang diadakan tersebut seharusnya dapat membantu guru-guru IPS dalam meningkatkan keprofesionalannya. Materi yang dibahas tidak hanya berisikan teori tentang perencanaan pembelajaran, pelaksanaan pembelajaran, evaluasi hasil pembelajaran tetapi juga bagaimana seorang guru mengaplikasikannya didalam kelas yang mereka laksanakan dalam Peer Teaching.

Ada beberapa kendala umum yang mereka hadapi dalam melaksanakan kegiatan MGMP ini diantaranya; sebagian peserta MGMP kurang serius dalam mengikuti kegiatan terbukti dengan masih banyaknya peserta yang datang terlambat, sebagian 
peserta mereka cenderung tidak mempraktekkan apa yang telah mereka peroleh pada kegiatan MGMP dalam proses belajar mengajar di kelas, dari narasumber yang diundang kadang kala mereka tidak datang sehingga kegiatannya tidak berjalan seperti yang dijadwalkan dan Dinas Pendidikan masih belum mendukung sepenuhnya pelaksanaan MGMP yang disebabkan keterbatasan biaya, dana itu digunakan untuk biaya transportasi peserta, untuk narasumber, konsumsi peserta, tapi dana tersebut kurang mencukupi sehingga peserta MGMP mengeluarkan biaya tambahan.

Berdasarkan latar belakang yang telah diuraikan, maka penulis tertarik melakukan penelitian mengenai Analisis Pelaksanaan MGMP IPS
SMP/MTS dalam Meningkatkan
Profesionalitas Guru di Kabupaten
Sijunjung Tahun 2017. Menurut Saondi, MGMP mempunyai tujuan tidak lain menumbuhkan kegairahan guru untuk meningkatkan kemampuan dan keterampilan dalam mempersiapkan, melaksanakan, dan mengevaluasi program kegiatan belajar mengajar dalam rangka meningkatkan sikap percaya diri sebagai guru. Menyetarakan kemampuan dan kemahiran guru dalam melaksanakan kegiatan belajar mengajar sehingga dapat menunjang usaha peningkatan dan pemerataan mutu pendidikan, mendiskusikan permasalahan yang dihadapi guru dalam melaksanakan tugas sehari-hari dan mencari penyelesaian yang sesuai dengan karakteristik mata pelajaran guru kondisi sekolah dan lingkungan, membantu guru memperoleh informasi teknis edukatif yang berkaitan dengan kegiatan keilmuan dan iptek, kegiatan pelaksanaan kurikulum, metodologi, dan sistem evaluasi sesuai dengan mata pelajaran yang bersangkutan serta saling berbagi informasi dan pengalaman dalam rangka menyesuaikan perkembangan ilmu pengetahuan dan teknologi (Saondi 2010:81).

Guru merupakan sebuah profesi, dalam KBBI profesi diartikan sebagai bidang pekerjaan yang dilandasi keahlian tertentu. Sedangkan dalam Peraturan Pemerintah Nomor 74 Tahun 2008 Pasal 1, guru adalah pendidik profesional dengan tugas utama mendidik, mengajar, membimbing, mengarahkan, melatih, menilai, mengevaluasi peserta didik pada pendidikan anak usia dini jalur pendidikan formal, pendidikan dasar, pendidikan menengah.

Dalam Kamus Besar Bahasa Indonesia disebutkan arti profesi adalah bidang pekerjaan yang dilandasi keahlian tertentu. Profesionalitas diartikan sebagai mutu, kualitas, dan tindak tanduk yang merupakan ciri suatu profesi atau orang yang profesional. Profesionalitas ditandai dengan adanya standar atau jaminan mutu seseorang dalam melakukan suatu upaya profesional. Profesional adalah 
pekerjaan atau kegiatan yang dilakukan seseorang dan menjadi sumber penghasilan kehidupan yang memerlukan keahlian,kemahiran, atau kecakapan yang memenuhi standar mutu atau norma tertentu serta memerlukan pendidikan profesi ( UU RI No 14 tahun 2005)

Berdasarkan Undang-Undang Republik Indonesia Nomor 14 Tahun 2005 dan Peraturan Menteri Nomor 16 tahun 2007 kompetensi profesional adalah merupakan kemampuan penguasaan materi pembelajaran secara luas dan mendalam yang memungkinkan membimbing peserta didik memenuhi standar kompetensi yang ditetapkan dalam standar nasional. Kompetensi profesional adalah penguasaan materi pelajaran yang terdiri dari penguasaan bahan yang diajarkan, penguasaan dan penghayatan atas landasan dan wawasan kependidikan dan keguruan, penguasaan proses-proses kependidikan, keguruan, dan pembelajaran siswa memungkinkan membimbing peserta didik memenuhi standar kompetensi yang ditetapkan dalam Standar Nasional Pendidikan (Mulyasa, 2008:135).

\section{Ruang lingkup kompetensi} profesional guru secara umum dapat diidentifikasi sebagai berikut :

1. Mengerti dan dapat menerapkan landasan kependidikan baik filosofi, psikologis, sosiologis, dan sebagainya.
2. Mengerti dan dapat menerapkan teori belajar sesuai taraf dan perkembangan peserta didik.

3. Mampu menangani dan mengembangkan bidang studi yang menjadi tanggung jawabnya.

4. Mengerti dan dapat menerapkan metode pembelajaran yang bervariasi.

5. Mampu mengembangkan dan menggunakan berbagai alat, media dan sumber belajar yang relevan.

6. Mampu mengorganisasikan dan melaksanakan program pembelajaran.

7. Mampu melaksanakan evaluasi hasil belajar peserta didik.

8. Mampu menumbuhkan kepribadian peserta didik.

Berdasarkan uraian diatas, tampak bahwa kompetensi profesional merupakan kompetesi yang harus dikuasai oleh guru dalam kaitannya dengan pelaksanaan tugas utamanya mengajar

(Mulyasa,2008:138). Permendiknas Nomor 16 Tahun 2007 tentang Standar Kualifikasi Akademik dan Kompetensi Guru,selain kompetensi profesional. Ada 4 Kompetensi yang harus dimiliki guru yaitu, kompetensi kepribadian, kompetensi sosial, kompetensi pedagogik, dan kompetensi profesional. Keempat kompetensi tersebut tidak berdiri sendiri, tetapi saling berhubungan dan saling mempengaruhi satu samalain.

Seorang guru yang dikatakan sebagai guru profesional adalah guru yang memiliki kompetensi dalam melaksanakan program pembelajaran. Pendapat ini diperkuat oleh Syaefudin, 
bahwa guru profesional adalah guru yang memiliki seperangkat kompetensi (pengetahuan, keterampilan, dan perilaku) yang harus dimiliki, dihayati, dan di sukai oleh guru dalam melaksanakan tugas profesionalnya. (Syaefudin,2009:49).

\section{METODOLOGI PENELITIAN}

$\begin{array}{lll}\text { Jenis } & \text { penelitian } & \text { Deskriptif } \\ \text { pendekatan } & \text { Kualitatif. } & \text { Penelitian } \\ \text { Deskriptif } & \text { menurut } & \text { Suharsimi } \\ \text { Arikunto } & (2006: 12) & \text { penelitian }\end{array}$

kualitatif dilakukan dan terjadi secara ilmiah, apa adanya dalam situasi normal, tidak dimanipuasi keadaan dan kondisinya. Selanjutnya menurut Moleong (2005:6) mendefenisikan bahwa penelitian kualitatif adalah penelitian yang bermaksud untuk memahami fenomena tentang apa yang dialami oleh subjek penelitian misalnya perilaku, persepsi, motivasi, tindakan. Secara holistik, dan dengan cara dalam bentuk kata-kata dan bahasa, pada suatu konteks khusus yang alamiah dan dengan memanfaatkan metode alamiah. Penelitian ini dilakukan di SMP N 6 Sijunjung Kecamatan IV Nagari Kabupaten Sijunjung. Tanggal 21 November-28 November 2017 pada pukul 09.30-14.30 Wib. Jumlah informan 6 orang terdiri dari 1 orang anggota Dinas Pendidikan Kabid SMP, 1 orang Ketua MGMP IPS Gugus 2, 1 orang Pengurus MGMP IPS SMP Gugus 2 dan 3 orang guru anggota MGMP IPS Gugus 2. Adapun sumber data primer dalam penelitian ini adalah peserta yang ikut dalam kegiatan MGMP IPS gugus II di SMP/MTSN Se-Kabupaten Sijunjung pada periode 2016-2017. Sedangkan data sekunder diperoleh dari Instansi-instansi Pemerintah yaitu LPMP dan Dinas Pendidikan Kabupaten. Teknik pengumpulan data dalam penelitian ini dilakukan dengan cara penelitian lapangan, yaitu terjun langsung di lokasi penelitian untuk mendapatkan data yang diperlukan. Pada penelitian ini, akan memilih informan dengan menggunakan purposive sampling. Artinya, sumber data dipilih melalui seleksi berdasarkan pertimbangan dan tujuan tertentu. H.B Sutopo (2006) menjelaskan bahwa dalam purposive sampling. Data diperoleh melalui beberapa cara sesuai dengan jenis penelitian yang digunakan yaitu dengan observasi, wawancara, dan dokumentasi. Teknik analisis data yang digunakan adalah pengumpulan data, reduksi data, penyajian data dan pengambilan kesimpulan.

\section{HASIL PENELITIAN DAN PEMBAHASAN}

Berdasarkan hasil penelitian Berdirinya MGMP IPS SMP merupakan tempat komunitas guru IPS dalam tingkatan sekolah menengah pertama baik sekolah negeri maupun sekolah swasta, wadah ini dijadikan tempat berkomunikasi dengan guruguru senior, yang telah berpengalaman dalam mengajar. Selain itu untuk membahas persoalan-persoalan yang terkait dengan materi bahan ajar, model 
belajar, rencana pengajaran, penilaian, masalah kepangkatan, dan penyamaan visi dan misi ke depan wadah tersebut akan dibawa. Peran pemecahan persoalan keseharian mengenai tugas guru mengajar dan penyiapan bahan ajar apa yang harus dibuat dan diberikan pada peserta didik, MGMP menjadi sarana yang dapat memerankan fungsi dan peranannya selama ini secara efektif.

MGMP IPS Gugus 2 mempunyai visi dan misi sebagai berikut :

Visi : Terwujudnya Guru IPS yang berkarakter, profesional, akuntabel, dan inovatif

Misi :

(a) Meningkatkan ketakwaan terhadap Tuhan yang Maha Esa

(b) Mewujudkan kebermaknaan MGMP IPS sebagai wadah pengembangan profesionalisme

(c) Meningkatkan kepekaan terhadap pengembangan IPTEK

(d) Menanamkan kepedulian terhadap lingkungan

(e) Mewujudkan guru IPS yang berkualitas dan berkreatifitas dalam pembelajaran.

Tujuan pelaksanaan MGMP IPS Gugus 2 di Kabupaten Sijunjung:

Tujuan Umum : Meningkatkan kerja peserta MGMP sehingga diharapkan guru lebih profesional dan dalam upaya pembinaan keprofesionalitasan guru secara berkelanjutan sesuai dengan pelayanan minimal dalam rangka penjaminan pendidikan nasional.
Tujuan Khusus : Meningkatkan kualitas guru dalam mengembangkan diri, menulis publikasi ilmiah, dan pembuatan karya inovatif. Serta meningkatkan kinerja dan karir guru secara berkelanjutan.

Hasil yang diharapkan dalam kegiatan MGMP gugus 2 diantaranya dapat mengetahui informasi teknis MGMP, dapat melakukan penyusunan rencana pelaksanaan pembelajaran, mampu menyusun PTK, mengetahui Pendidikan Karakter, mampu menulis karya ilmiah, mampu memecahkan permasalahan modul PKB. Pemilihan ketua dan sekretaris MGMP dipilih langsung oleh anggota MGMP satu gugus yang dirasa patut dan mampu mengemban tugas dalam kelancaran pelaksanaan MGMP IPS Gugus 2 Kabupaten Sijunjung.

Dengan dibentuknya

kepengurusan MGMP IPS Gugus 2 supaya melaksanakan tugas dengan baik dalam meningkatkan profesionalitas guru bersama temanteman guru lainnya. Profesionalitas disini yang dimaksud adalah guru harus memiliki standar kompetensi sesuai dengan Permendiknas nomor 16 tahun 2007 yaitu kompetensi pedagogik, kompetensi kepribadian, kompetensi sosial dan kompetensi profesional.

Pelaksanaan kegiatan MGMP dilakukan pada hari Selasa pukul 09.3014.20 Wib, untuk tempat pertemuan pelaksanaan kegiatan MGMP dilakukan di SMP Negeri 6 Sijunjung. SMPN 6 Sijunjung mempunyai ruangan khusus untuk kegiatan MGMP berbagai mata 
pelajaran yang di dukung dengan sarana dan prasarana lain seperti meja dan kursi yang cukup, infocus, printer dan saran pendukung lainnya. Penanggung jawab MGMP IPS dipegang oleh Kepala SMPN 6 Sijunjung, yang selalu melakukan monitoring dan memberikan arahan terhadap pelaksanaan MGMP. MGMP IPS Gugus 2 Kabupaten Sijunjung beranggotakan sebanyak 40 orang yang terdiri dari berbagai daerah di Kabupaten Sijunjung. Data informan peserta MGMP IPS Gugus 2 Kabupaten Sijunjung Tahun 2017 yaitu sebanyak 44 orang yang diketui oleh Pardi, S.Pd. Susunan kepengurusan MGMP periode 2017 mempunyai beberapa program kerja yaitu : (a) Penulisan PTK (b) Beda SKL (c) Penyusunan Bank Soal (d) PPK (e) Pembahasan Modul PKB (f) Pemberdayaan kegiatan MGMP (g) Pengelolaan Nilai berbasis ICT. Kegiatan MGMP ini sudah berjalan dengan lancar. Selain itu, peran antara anggota dan pengurus yang terjalin sangat baik sehingga kegiatan dapat berjalan lancar. Kendala dalam pelaksanaan MGMP IPS gugus 2 dintaranya pendanaan dari Dinas Pendidikan yang dananya masih minim, pelaksanaannya masih dikatakan belum sepenuhnya sesuai jadwal, partisipasi dan keaktifan guru-guru perlu ditingkatkan lagi dalam pelaksanaan kegiatan MGMP IPS SMP ini, supaya kualitas pembelajaran IPS di Kabupaten Sijunjung ini membaik dari semula. Kemudian etos kerja guru perlu ditingkatkan lagi untuk dapat mengembangkan kualitas pembelajaran.
Upaya yang dilakukan oleh forum MGMP dalam meningkatkan profesionalitas guru diantaranya membahas segala sesuatu hal yang berkaitan dengan profesi keguruan seperti pembuatan perangkat pembelajaran, penulisan PTK, beda SKL, penyusunan Bank soal, pembahasan modul, pengolahan nilai berbasis ICT. Pembahasan silabus juga menjadi hal pokok yang dibahas dalam MGMP karena akan berkaitan pada penulisan RPP. Selain itu MGMP juga membantu guru serta memberi arahan mengenai tugas profesi guru dinas juga memfasilitasi kegiatan dengan bantuan dana dan biaya demi terlaksananya MGMP di Kabupaten Sijunjung.

Manfaat MGMP dalam meningkatkan profesionalitas guru SMP/MTS gugus 2 Kabupaten Sijunjung diantaarnya guru dapat berdiskusi dengan guru lain mata pelajaran yang sama, guru-guru dapat menjalankan tugas sesuai dengan fungsi keguruan dan sesuai dengan kode etik guru, membantu guru membuat perangkat pembelajaran. MGMP dapat menjadi bahan kajian dan pengembangan keilmuan administrasi pendidikan, menjadi masukan bagi pemerintah dalam hal meningkatkan profesionalitas guru. MGMP mampu membantu guru menguasai kompetensi sesuai standar pendidik yang disyaratkan dalam Standar Nasional Pendidikan, memotivasi guru untuk terus menerus meningkatkan kemampuan dan keterampilan dalam merencanakan,melaksanakan, dan 
membuat program evaluasi pembelajaran. MGMP merupakan wadah yang paling dekat, murah, terjangkau, untuk mengimplementasikan pengembangan keprofesionalan secara berkelanjutan, guru dapat mengetahui berbagai informasi terbaru mengenai dunia pendidikan.

\section{PEMBAHASAN}

Berdasarkan penelitian yang telah ditemui peneliti saat di lapangan melalui Observasi, Wawancara, dan Dokumentasi maka diperoleh hasil penelitian sebagai berikut:

Pertama, kendala-kendala yang dihadapi dalam pelaksanaan MGMP IPS SMP Gugus 2 di Kabupaten Sijunjung diantaranya masalah pendanaan bantuan dana yang diberikan oleh APBD masih kurang, sehingga memerlukan dana partisipasi/dana mandiri dari anggota MGMP. Kemudian masih banyak guru yang belum memahami silabus, silabus merupakan hal terpenting yang harus dikuasai guru dalam pelaksanaan PBM. Permasalahan selanjutnya adalah dalam penulisan PTK. Masih banyak guruguru yang kurang mengerti mengenai penulisan PTK

Kedua, upaya MGMP dalam meningkatkan profesionalitas guru dintaranya, upaya dari pemerintahan/ dinas Pendidikan demi terlaksananya kegiatan MGMP yang dirasa mampu untuk dapat meningkatkan kualitas pembelajaran dan profesionalitas guru adalah dengan memberikan bantuan dana dari APBD dengan cara mengajukan proposal pendanaan kepada dinas pendidikan, upaya dari pengurus kegiatan MGMP adalah dengan mengurus berbagai kebutuhan guru yang dirasa perlu dan menjadikannya suatu program pada kegiatan MGMP yang akan dilaksanakan, upaya dari antar sesama guru dalam meningkatkan kualitas pembelajaran adalah dengan saling berdiskusi mengenai masalah yang ditemui di sekolah masing-masing. Tidak hanya itu sesama anggota guru dapat saling membantu dalam menyelesaikan tugas pokok guru seperti dalam penyusunan RPP maupun penulisan PTK.

Ketiga, manfaat MGMP dalam meningkatkan profesionalitas guru SMP/MTS gugus 2 Kabupaten Sijunjung diantaranya, dalam kegiatan MGMP guru-guru di siapkan menjadi guru profesional yang dapat meningkatkan kualitas pembelajaran, MGMP dapat menjadi bahan kajian dan pengembangan keilmuan administrasi pendidikan, menjadi masukan bagi pemerintah dalam hal meningkatkan profesionalitas guru serta melahirkan guru-guru yang profesionalitas yang tinggi dalam dunia kerja, dalam kegiatan MGMP dapat mengembangkan proses pembelajaran berbasis komputer,teknologi Informasi dan komunikasi. Melalui kegiatan MGMP mampu membantu guru menguasai kompetensi sesuai standar pendidik yang disyaratkan dalam Standar Nasional Pendidikan. Memotivasi guru untuk terus menerus 
meningkatkan kemampuan dan keterampilan dalam merencanakan, melaksanakan, dan membuat program evaluasi pembelajaran. Untuk mengembangkan kemampuan dan kemahiran guru dalam melaksanakan pembelajaran di kelas dengan berbagai media pembelajaran guna untuk meningkatkan mutu pendidikan. Berdiskusi untuk membahas permasalahan yang dihadapi dan dialami oleh guru dalam melaksanakan tugas sehari-hari dan mencari solusi alternatif pemecahannya sesuai dengan karakteristik siswa, guru, kondisi sekolah dan lingkungan. Membantu guru memperoleh informasi teknis edukatif yang berkaitan dengan kegiatan keilmuan, perkembangan teknologi, pelaksanaan kurikulum, saling berbagi informasi dan pengalaman dalam rangka mengikuti dan menyesuaikan diri dengan ilmu pengetahuan dan teknologi.

\section{PENUTUP}

\section{Kesimpulan}

Hasil penelitian yang telah dilakukan menunjukkan beberapa kendala dalam pelaksanaan MGMP IPS Gugus 2 di Kabupaten Sijunjung, adalah sebagai berikut, (a) Sumber dana dari APBD yang belum mencukupi pelaksanaan kegiatan MGMP IPS di Kabupaten Sijunjung, (b) Terdapat beberapa etos kerja guru yang bersangkutan memang rendah yang dilihat berdasarkan UU No.14. Tahun 2005 tentang Guru dan Dosen yang harus mempunyai 4 kompetensi profesional, beberapa guru kurang mengembangkan hasil yang diperoleh melalui kegiatan program kerja MGMP dan kurang berpartisipasi dalam kegiatan MGMP. (c) masih ada beberapa anggota MGMP yang sering datang terlambat

$$
\text { Upaya-upaya MGMP IPS }
$$

Gugus 2 Kabupaten Sijunjung dalam pengembangan Kompetensi Profesional guru diantaranya, (a) Upaya dari pemerintahan adalah dengan memberikan bantuan dana dari APBD untuk pelaksanaan kegiatan MGMP (b) Upaya dari pengurus kegiatan MGMP adalah dengan menyusun program MGMP sesuai dengan kebutuhan guru

(c) Upaya dari sesama guru adalah saling berdiskusi mengenai masalah yang ditemui di sekolah masingmasing, membantu menyelesaikan tugas pokok guru seperti penyusunan RPP, penulisan PTK, pemecahan persoalan keseharian mengenai tugas guru mengajar dan mempersiapkan bahan ajar yang harus dibuat dan diberikan pada peserta didik .

Manfaat yang didapat guru-guru dalam pelaksanaan kegiatan MGMP di antaranya, (a) Guru dapat mendiskusikan permasalahan yang dihadapi dan dialami oleh guru dalam melaksanakan tugas sehari-hari dan mencari solusi alternatif pemecahannya. (b) Guru memperoleh informasi edukatif yang berkaitan dengan kegiatan ilmu pengetahuan dan teknologi, kegiatan kurikulum, pengolaan nilai, guru dapat saling bertukar informasi dan pengalaman. 


\section{Saran}

1. Diharapkan partisipasi dan kesadaran guru anggota MGMP untuk dapat meningkatkan profesionalitas melalui kegiatan MGMP.

2. Sebaiknya pemerintah / Dinas pendidikan plebih memperhatikan lagi kebutuhan dana dari kegiatan MGMP supaya kegiatan dapat berjalan dengan lancar tanpa membebani anggota MGMP.

\section{DAFTAR PUSTAKA}

Azwir. 2006. Peranan MGMP Bahasa Inggris SMP Untuk Meningkatkan

Profesionalisme Guru Dalam

Pembelajaran Di Kota Padang. (Tesis) Padang: UNP

Kriyantono, Rachmad. 2010. Teknik Praktis Riset Komunikasi Jakarta : Kencana

Moleong,Lexy J.2005. Metodologi Penelitian Kualitatif. Bandung : PT.Remaja Rosdakarya.

Mulyasa, E. 2008. Standar Kompetensi dan Sertifikasi Guru. Bandung : PT.Remaja Rosdakarya.

Peraturan Pemerintah No. 74 Tahun 2008.

Retnoningsih Ana.2005. Kamu Besar Bahasa Indonesia. Semarang : CV. Widya Karya

Soetjipto.2009. Profesi Keguruan. Jakarta : Rineka Cipta.

Saondi, Ondi dan Aris Suherman.2010. Etika Profesi Keguruan.
Bandung : PT.Refika Aditama.

Sa'ud, Udin Syaifudin. 2009. Pengembangan Profesi Guru. Bandung: CV. Alfabeta.

Suharsimi, Arikunto. 2006. Prosedur Penelitian Suatu Pendekatan Praktik. Jakarta: PT. Rineka Cipta.

Sutopo, H. B.2006. Metodologi Penelitian kualitatif dasar teori dan terapannya dalam penelitian. Surakarta : Universitas Sebelas Maret.

UU. No. 14. Tahun 2005. Tentang Guru dan Dosen. Pasal 41 dan 42 